\title{
Humaniora, elektronisk publicering og forskningsbibliotekerne
}

\author{
Af Gunner Lind
}

\begin{abstract}
En rakke strukturelle forhold har gjort, at humaniora i langt mindre grad end naturvidenskab og medicin har lagt om til elektronisk publicering af forskningsresultaterne. Det er forhold der dels er økonomisk-organisatoriske, dels skyldes mangel på tilfredsstillende tekniske løsninger. I begge sammenhoenge kan forskningsbibliotekerne indgå i nye løsningsmodeller, til gavn for både humanisterne og bibliotekerne.
\end{abstract}

\section{Indledning}

Humanisternes univers er først og fremmest tekster. Humanistiske fagfolk er ekstremt flittige tekstforbrugere og tekstproducenter, og en meget stor del af den ikke videnskabelige tekst, der produceres i samfundene, har forbindelser til humaniora. Det gør humanisternes adfærd og ønsker centrale for forskningsbibliotekerne.

Denne tekst er et forsøg på at gennemtænke samspillet, sådan som det ser ud for en universitetsansat humanist med førstehånds kendskab både til IT og til publikationsvirksomhed, men uden biblioteksfaglig baggrund. Det er ikke videnskabelige resultater, der lægges frem, men et forsøg på en strategisk analyse. Lige nu står verden midt $i$ en generel overgang fra at publicere på papir med andre brugsformer som sekundære, til at publicere online med versioner på papir som en afledet mulighed. Som bekendt tenderer denne udvikling mod at gøre bibliotekernes rolle mindre. Men det er ikke afgjort, hvor meget mindre. Lige nu er den vigtigste model i fremgang den, hvor papirudgaver forsvinder helt eller bliver brugsmæssigt uden relevans. Brugen hviler på servere under forlagets kontrol, og biblioteket er et indkøbsbureau, der formidler licenser på brugerkredsens vegne, samt en leverandør af værktøjer til søgning i det materiale der er i licens (sammen med bibliotekets trykte materiale). Det fungerer på mange måder godt; men efter min vurdering er der to langsigtede problemer for brugerne og for almenheden i denne model. Det mest åbenlyse er stabiliteten i tilgangen på længere sigt. 
Private firmaer, selv "gamle" og store firmaer, har en forbløffende kort gennemsnitlig levetid. (Dunne \& Holmes, 1994: 120.) Al historisk erfaring tyder på at stabil opbevaring af information næsten udelukkende sker i offentlige institutioners regi. For bibliotekerne som institution er det problematisk at deres rolle som licensformidlere meget vel kan gøres overflødig af andre salgsformer, og deres rolle som søgeleverandører af andre søgemaskiner. Det er altså en offentlig interesse at bibliotekerne bevarer funktioner, der gør det muligt for dem at overleve som institutioner, og at de i det mindste ikke mister alle funktioner som egentlige depoter for materiale.

Humanisterne er i bagtroppen i bevægelsen mod elektronisk publicering. Det skyldes ikke kun at de elsker bøger. Det har også en række tungere grunde, som vil blive gennemgået i det følgende. Når humanisterne - mere eller mindre nødtvunget - forlader publikation på papir, vil det være en fundamental omvæltning for forskningsbibliotekerne. Men efter min opfattelse kan det også være nøglen til at give forskningsbibliotekerne en mere central rolle i den nye elektroniske publikationsverden, end der ellers er lagt op til. Det vil være til gensidig gavn for bibliotekerne såvel som for humanisterne.

\section{Humanioras vilkår}

For at forstå humanisternes situation kan det være nyttigt at ridse op, hvordan de adskiller sig fra forskerne inden for naturvidenskab.

Sammenlignet med naturvidenskaberne er humanisterne meget få. (Det samme gælder de samfundsvidenskabelige forskere, som på de fleste punkter deler vilkår med humanisterne). Man kan få et andet indtryk, hvis man tæller videnskabsfolk i medierne. Det skyldes imidlertid kun, at humanisternes og samfundsforskernes aktiviteter i højere grad retter sig direkte mod den brede offentlighed.

Når der er få aktive i forhold til feltets bredde, får de enkelte forskningsprodukter en lang aktualitetsperiode. Videnskabelige tekster betragtes som aktuelle i 10-20 år og kan have en nyttig levetid på over hundrede år. Det betyder, at kun meget velkendte, velbeskrevne og helst populære tekniske formater er relevante for humanister. Det er de eneste, der har en realistisk konverteringsvej frem i tiden. Det betyder også, at arkivstabilitet har en meget høj prioritet for hele humanioras tekstmasse, ikke bare for udvalgte, klassiske tekster.

Humanisterne er også fattige. Det skyldes ikke bare politik, men at humanistisk forskning kun i begrænset omfang har behov for at manipulere ting. Humanisterne har så små driftsbudgetter, at publikation af forskningens resultater er en ganske væsentlig del af de samlede omkostninger ved forskningsaktiviteten. I naturvidenskab og medicin er omkostningerne ved at gennemføre selve forskningen så store, at kommunikation af resultaterne relativt set er en billig aktivitet.

Små tal og små penge betyder, at de humanistiske fagfolk kun har ringe interesse som marked for publikationer. Derfor bliver en meget stor del af publikationerne subsidieret. Kun det engelske sprogområde er stort nok til, at en væsentlig del af den videnskabelige kommunikation foregår på almindelige markedsvilkår. På det lille danske marked er støtte så indlysende nødvendig, at der er blevet skabt en generøs støttekultur. Mængden af støttekroner er stor nok til, at der publiceres rigtig mange skrifter, som praktisk taget ikke finansieres gennem salg. De fattige humanister har altså, noget paradoksalt, ganske mange midler, som de ikke kan disponere frit over, men som traditionelt allokeres til deres publikationsvirksomhed af offentlige og private fonde.

På mange måder er forholdene på humaniora således ideelle for non-profit publikationsmodeller, finansieret ved reallokering af de allerede eksisterende midler. Men en principiel - for slet ikke at tale om en påbudt - overgang til non-profit publicering vil ikke være uden ulemper. Nogle dele af humaniora har et stort ikke-videnskabeligt publikum. Så stort, at det har kommerciel interesse. Det gælder først og fremmest mit eget felt, historie, men mange andre dele af humaniora producerer i det mindste visse ting, der kan sælges. Her bevæger vi os fra universitetsforlagenes og de specialiserede tidsskriftsforlags verden ind i den verden der er domineret af store kommercielle medievirksomheder. Her blandes videnskabelig og ikke-videnskabelig kommunikation. Vel at mærke på en måde, som er langt mere effektiv i spredningen af humanioras viden til den interesserede almenhed, end man på nogen måde kan forestille sig, at non-profit aktiviteter kan blive. Publicering for profit er altså ganske ofte en god ting for mange humanister. Humanisterne vil være dårligt tjent med 
modeller, der binder dem til non-profit publikation, for det vil lamme den mest velfungerende del af deres fageksterne publikationsvirksomhed.

Den teknologiske kompetence i humanistiske institutioner varierer meget. Groft sagt er der et skel mellem universiteter, hvor it-kompetence er centraliseret i serviceenheder langt fra forskerne, og museer, arkiver og biblioteker, hvor informationsteknologi er central for hele institutionens daglige aktiviteter. Få humanister bruger informationsteknologi til forskningsformål. Samlet set er det kun små og mindre typiske grupper af humanistiske forskere, der er i stand til at være teknisk innovative på egen hånd, og potentialet til at udvikle ny teknik til egne behov er lavt. Dette potentiale er tilmed faldet gennem mange år i takt med at kommercielle programmer er blevet bedre til at dække humanisternes basale behov. Inden for mit eget fag, historie, det største af alle humanistiske fag, kan man se den faldende interesse i lukningen af det vigtigste specialiserede tidsskrift. (History \& Computing, 1989-2002) Historie er formodentlig et ekstremt eksempel. Historikerne forsker i menneskers sociale liv i fortiden, og har derfor let ved at bruge de værktøjer, som håndterer informationssiden af vores eget liv i nutiden. Det er evident, at der er humanistiske discipliner, som lingvistik, hvor dagsordenen er anderledes, og den tekniske kompetence meget højere. Men den generelle mekanisme, at et bedre udbud af kommercielle værktøjer (og bedre faglige specialværktøjer fra akademiske institutioner) sænker behovet for at kunne udvikle ny teknik selv, gør sig gældende overalt. Humanisterne, især universitetshumanisterne, er altså meget afhængige af løsninger, andre har lavet, og har rigtig meget brug for mere teknisk kompetente partnere.

\section{Kommunikationens varianter}

Lige som på andre videnskabelige felter kan humanisternes trykbaserede kommunikation deles op i tidsskrifter og bøger. Det er velkendt, at humanisterne lægger relativt stor vægt på bøgerne. På trods af, at humaniora også rummer talrige og veletablerede videnskabelige tidsskrifter og en stor del af den samlede videnskabelige produktion har artikelform, spiller publikation i bogform kvantitativt og kvalitativt en meget større rolle end i naturvidenskab og medicin.

Den vigtigste grund til bøgernes position er formodentlig humanisternes ringe antal i forhold til forsk- ningsfrontens bredde inden for de fleste discipliner. Forskningsfronten er dårligt defineret når der kun arbejder få, spredt ud over et stort område. Det betyder, at det ikke er så vigtigt at kommunikere hurtigt, som det bedst sker gennem artikler. Der er et større potentiale $\mathrm{i}$ at tage den tid, der skal til, for at producere et større værk, som kan interessere en større andel af de aktive. Under alle omstændigheder er humanisternes tendens til at fastholde bøger som et væsentligt element i publikationsstrukturen så stabil, at det er meget usandsynligt at det bare er en vane, der let kan laves om. Den må være betinget af strukturelle forhold af blivende karakter.

\section{Kommunikationens betingelser: tidsskrifter}

Hvis de økonomiske rammer er på plads, er elektronisk udgivelse af videnskabelige tidsskrifter som bekendt en teknisk og brugsmæssig succes. De enkelte artikler distribueres glimrende som e-tekst. De er ikke længere, end at de kan håndteres tilfredsstillende på en skærm eller som hjemmelavet print on demand på en standard printer. Selve tidsskriftet som enhed sløres i de fleste elektroniske distributionsformer, men det er sjældent noget problem for brugerne. Overgang til elektronisk publikation (eller dobbelt publikation på papir og elektronisk) er altså tilfredsstillende for både tidsskrifter og brugere, forudsat den økonomiske side af sagen er i orden.

Et mindre antal humanistiske tidsskrifter publiceres på markedsbetingelser af kommercielle forlag eller markedsorienterede universitetsforlag. De fleste tidsskrifter udgives imidlertid af videnskabelige foreninger eller lignende organisationer, uden at et forlag er involveret, eller med små non-profit forlag som distributører. Rigtig mange tidsskrifter modtager økonomisk støtte på produktionssiden. Det gælder en del af de, der udkommer via forlag, og langt de fleste af de andre. Støtten er ikke nødvendigvis i kontanter til trykomkostninger og lignende. Det kan også være værtsinstitutioner, som dækker omkostninger eller finansierer lønninger.

Tidsskrifter, der udgives af forlag, følger naturligvis forlagenes generelle politik. Som bekendt er mange naturvidenskabelige tidsskrifter blevet en rigtig god forretning ved overgangen til elektronisk publikation, fordi det har vist sig, at adgangen til baserne har kunnet sælges til langt mere end produktionsomkostningerne. Det har gjort det let at finansiere den tekniske 
omlægning og attraktivt for udgiverne at sætte fart på udviklingen. Det vil ikke kunne gentages på humaniora, i hvert fald ikke i samme omfang. De humanistiske institutioner er mere fattige, og tidsskrifternes andel af private abonnenter er højere. Men man kan se, at mange humanistiske og samfundsvidenskabelige tidsskrifter, som udgives i et stort forlags regi, følger med over i elektronisk publikation (eller kombineret tryk/elektronisk publikation) som led i en generel omlægning af forlagets tidsskriftportefølje. Det har de samme virkninger som i naturvidenskab og medicin: højere priser - nogle gange meget høje - men forhøjet tilgængelighed og brugbarhed.

De øvrige tidsskrifter er gennemgående strandet. Enten har de slet ikke nogen elektronisk udgave, eller de har kun gamle numre lagt ud på nettet i dårlig organisation på hjemmebryggede netsteder. De er strandet, fordi organisationen bag dem ikke besidder teknisk kompetence til at implementere mere tilfredsstillende modeller, og heller ikke har organisatorisk kompetence til at etablere en levedygtig økonomisk model. Abonnementsindtægter er nødvendige, men kræver særlige løsninger på nettet. Støtte er også nødvendig, men har traditionelt haft tryk- og distributionsomkostningerne som argument. Der er brug for meget ny viden i mange kredse, og meget vilje til at finde nye løsninger, for at skabe en ny, fungerende økonomisk hybridmodel, der kan erstatte den traditionelle hybrid.

Humanioras tidsskrifter har altså problemer, og løsninger kan i meget høj grad involvere forskningsbibliotekerne. Det gælder især de tidsskrifter, som ikke har fået taget hul på en seriøs elektronisk (parallel) udgivelse på grund af mangel på teknisk kompetence. For disse non-profit tidsskrifter vil forskningsbibliotekerne være de ideelle værter. Her findes der kompetence, og her er der en forpligtelse til langvarig opbevaring og tilgængelighed, som passer til humanioras behov.

Der er imidlertid brug for at få udviklet holdbare økonomiske modeller. Den rent 'grønne' model, hvor alle udgifter afholdes på udgiversiden, er ikke uden videre brugbar for tidsskrifter, som dækker en god del af deres udgifter ved abonnementer og legitimerer de tilskud de får med henvisning til trykomkostningerne. Det er nødvendigt at kombinere med kanaler for abonnementer - eller frivillige støttebidrag - der kan indgå i et non-profit kredsløb, og der er brug for omkanalisering af økonomisk støtte. På det sidste punkt er det velorganiserede og relativt velhavende danske, humanistiske miljø faktisk vel forberedt. Et stort antal tidsskrifter ville være tjent med at få støtte i form af gratis adgang til en elektronisk publikationsfunktion (inklusive layout og gerne tekniske redaktions- og forlagsfunktioner) i stedet for at få støtte i penge og selv skulle organisere det hele som deltidsarbejde udført af forskerne selv.

\section{Bøgerne: de avancerede publikationsformer}

Lige nu er der meget der peger på, at bøgerne langt om længe er ved at finde elektroniske former, der kan tilfredsstille mange brugere. Dels takket være udviklingen af specialiserede læseapparater, dels gennem den stilfærdige vækst i print on demand. Bøger er for lange til at læses på en skærm i en almindelig arbejdsopsætning eller skrives ud i løse ark på en almindelig printer.

Humanisterne har imidlertid temmelig stadig temmelig alvorlige problemer med elektronisk distribution af mange af de tekster, de plejer at publicere som bøger. Problemerne er ikke egentlig tekniske, i hvert fald ikke altid. På områder, som jeg vil beskrive som problematiske, foreligger der faktisk mange eksempler på fornemme løsninger af de tekniske problemer. Løsningerne er bare af en karakter, så det er vanskeligt at forestille sig, at de er levedygtige og arkivsikre på længere sigt. Hvis løsningerne skal overføres til nye tekster, kræves der en omfattende arbejdsindsats. Det betyder, at disse løsninger ikke vil blive udbredte, hvad der igen har en negativ indvirkning på arkivsikkerheden på længere sigt. Robuste løsninger må i alle deres led, både filformater og programværktøjer, være udstrakt anvendt, også uden for den akademiske verden.

To vigtige eksempler på denne problemstilling er navigation i lange tekster og flerlagstekst.

I de humanistiske forskeres bøger ses behovet for navigationsredskaber tydeligt. Der er registre - ofte flere slags - indholdsfortegnelser og andre samlinger af henvisninger der kan fungere som navigationsinstrumenter i de lange tekster. De lange humanistiske tekster er ikke altid beregnet på at blive læst fra ende til anden. De bliver det i endnu mindre grad. Især af forskerne selv, som i høj grad søger efter bestemte oplysninger eller fokuserer på bestemte dele. Naviga- 
tionsredskaberne spiller ofte sammen med en kompleks segmentering af de lange tekster: Hierarkisk segmentering i mange niveauer og/eller opdeling i blokke af forskellig art.

Flerlagstekst er et ønskemål som er vanskeligt at nå i ret høj grad på papir. En stor del af humanistisk forskning drejer sig om edition i bred forstand. Det drejer sig om aktiviteter som filologisk tekstudgave, historisk kildeudgave, kunsthistorisk oeuvrekatalog. I den type arbejde bliver det samme værk, eller den samme genstand, meget ofte præsenteret i flere varianter. Desuden repræsenteres de på flere forskellige måder ud af et bredt repertoire af repræsentationsmåder. I gengivelsen af værker i tekst kender vi for eksempel faksimile, afskrift, rekonstruktion, oversættelse, resume, stikord. (Lind, 2000) De mange forskellige måder er optimale for hver sin brug. Ideelt ønsker man gerne at integrere flere måder som 'lag' $i$ et samlet kompleks. På papir møder man dobbeltsprogede udgaver, resume- og detailfortegnelser og andre forsøg på samlet at præsentere flere relevante måder i sammenhæng. De fleste editioner præsenterer deres stof i flere former, om ikke andet, så som søgeredskab. Men tæt integration af mange måder for repræsentation er der, som sagt, sat snævre grænser for.

\section{Skrøbelige løsninger går hinsides bogen}

Rent teknisk giver elektroniske løsninger en vifte af avancerede muligheder for hurtig navigation og for præsentation af mange lag. Det kan man konstatere på netsteder der bringer avancerede elektroniske tekstudgaver som Søren Kierkegaards Skrifter (http://sks.dk/), Mitteldeutsche Selbstzeugnisse der Zeit des Dreißigjährigen Krieges (http://www.mdsz. thulb.uni-jena.de/sz/index.php) eller Bodleian Library Broadside Ballads (http://www.bodley.ox.ac. uk/ballads/). Mange museer har også avancerede netsteder som i betydeligt omfang præsenterer forskningsresultater. Her er en anden form for integration af varianter, nemlig af tekst, billede, lyd og video, $\mathrm{i}$ forgrunden. Potentialet for at angribe kendte udfordringer med nye, lovende værktøjer har fået mange humanister til at eksperimentere med elektronisk publikation.

Disse løsninger er ofte fremragende. De bør også være det, da de er meget dyre at lave. Men som en platform for videnskabelig tekst er der tale om en blindgyde. De fremragende netsteder er tragiske skønheder, dømt til en tidlig død, sammenlignet med de trykte udgaver, som de baserer sig på eller er alternativer til. Det kan man hurtigt konstatere ved at studere, hvordan netstederne teknisk er lavet. Selvfølgelig benytter man sig af de mest udbredte og standardiserede værktøjer, der findes i dag, som Javascript og PHP filer fra SQL baserede servere. Men det er ikke rigtig robust med den humanistiske videnskabs målestok. Alle ingredienserne i den tekniske løsning vil være erstattet af nye versioner eller eksemplarer inden for et par år i gennemsnit. Inklusive en del af de grundlæggende fil- og programformater. Og helheden er bundet op til en bestemt server med en bestemt konfiguration, som drives af en bestemt institution, der langt fra altid har langtids opbevaring og tilgængeliggørelse som sit formål, eller bare udsigt til langsigtet finansiering. Det er svært at forestille sig, at en sådan løsning kan være holdbar $i$ årtier eller århundreder. Standardiserede formater kan gøre det rimeligt let at konvertere data fremad, men løsningernes samlede funktionalitet er afhængig af meget mere end data.

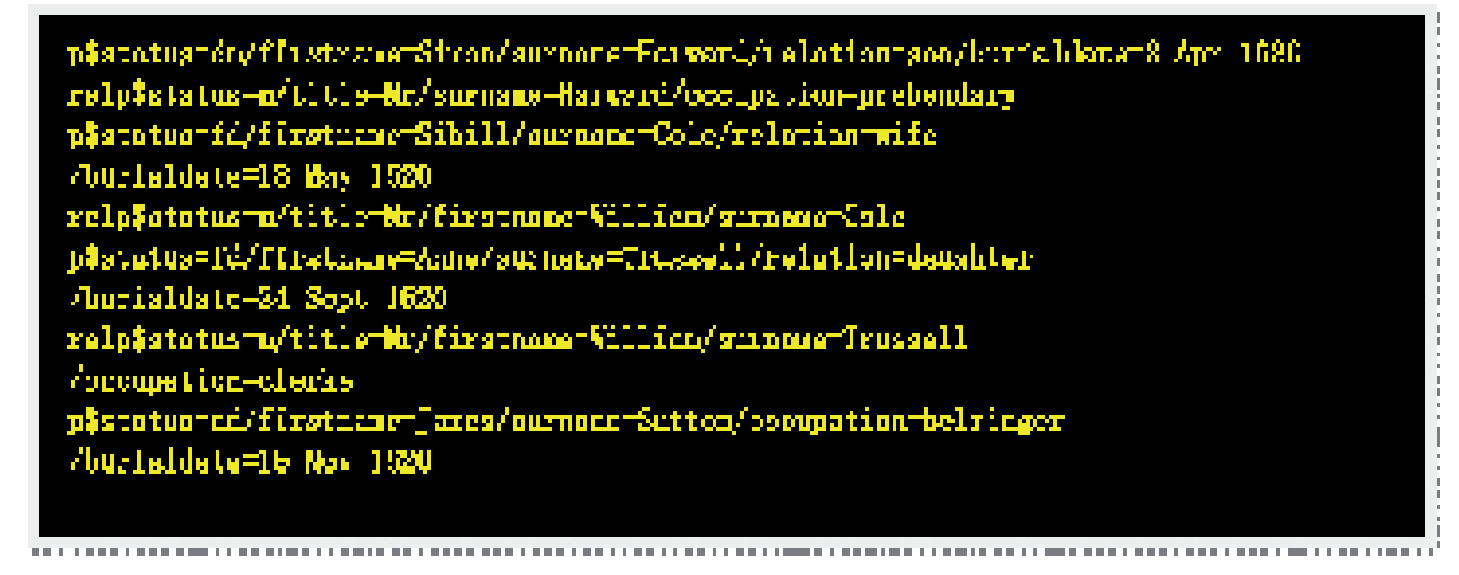


Som illustration kan jeg give et billede af et klip af data fra Kleio tekstdatabasesystemet, udviklet 1978 og frem ved Max-Planck-Institut für Geschichte. (Thaller, 1992) Det er et godt eksempel på, hvor gammel humanisters interesse har været for at bruge informationsteknologien til andet end tal. Men først og fremmest på afhængigheden af social kontekst. Kleio var grundlag for en række banebrydende og nu klassiske forskningsprojekter ved MPIG. Ved denne institution og en del andre blev der oparbejdet betydelige mængder tekst og andre data i Kleio formatet. Indtil 1990erne var det state of the art $\mathrm{i}$ informationsteknologi til historisk forskning. Men det blev gradvist fortrængt af mindre ydedygtige, men lettere anvendelige, kommercielle databasesystemer, selv efter at entusiaster havde skaffet penge til at få oversat system og dokumentation til engelsk. (Woollard \& Denley, 1993)

Hvis tekster, mærket op i det gamle system, har et liv i dag, er de blevet konverteret med store omkostninger, fordi udgangspunktet har været så specielt. Og meget af den oprindelige funktionalitet vil være forsvundet, fordi den var bundet til egenskaber ved det oprindelige program. Hvad tilbyder for eksempel i dag automatisk lemmatisering ved søgning på latinske ord eller indbygget håndtering af den franske revolutionskalender? Uden programmets muligheder vil rationalet bag data sagtens kunne være væk. De serverbaserede løsninger er imidlertid endnu mere komplekse, og endnu mere afhængige af egenskaber ved programmer, der gør ren datakonvertering til en halv løsning. De er altså endnu mere sårbare.

Humanisternes praksis inden for elektronisk publikation viser den markante interesse for ambitiøse publikationsformer, hvor der nok kan leves tekniske løsninger, men disse løsninger ikke er opbygget på en måde, der gør dem tilstrækkelig robuste. I og med at nogle bestemte udfordringer kommer igen mange steder, burde der være mulighed for at skabe generelle løsninger af mere holdbar karakter. Der er langt igen, før man har robuste modeller, som vi kender det fra de facto standarden for korte og simple tekster, PDF: En teknisk model, hvor fuld funktionalitet for brugeren opnås med én datafil, baseret på et velkendt format, og ét program med en vifte af let benyttelige og til dels gratis programmer til rådighed; og en social succes der gør, at løsningens migration ind i fremtiden har høj sandsynlighed for at blive sikret.
Generelle løsninger, der svarer til humanisternes ønsker, vil næppe komme fra den kommercielle sektor, for ønskerne er meget specielle, i hvert fald hvis man skal slutte ud fra publikation på papir, hvor de mere avancerede humanistiske publikationsformer er sui generis. Her er altså eksempler på de opgaver, som et samarbejde mellem humanistiske forskere og mere teknisk kompetente partnere kunne gøre noget ved.

\section{Konklusion: Det falles felt}

Sagkyndige læsere kan mene, at jeg bjæffer op ad alt for velkendte træer. Der er i adskillige år blevet arbejdet med elektronisk publicering mange steder, både biblioteker og forskningsinstitutioner, og antallet af steder synes at være stigende. (van Westrienen \& Lynch 2005; Lynch \& Lippincott 2005; Kennan $\&$ Kingsley 2009.) Projekter, der adresserer de mere avancerede former for elektronisk publikation, har stået højt på dagsordenen i de kredse, der arbejder med humanistisk informatik, siden opstarten af Text Encoding Initiative i 1987. Der er kort sagt ingen dele af den dagsorden, som ridses op her, der er egentlig nye.

Det centrale er imidlertid den strategisk bestemte kombination af spørgsmålene. Hvis jeg har ret i, at forskningsbibliotekerne er langt de bedste værter for elektronisk publikation, så bør de humanistiske forskere og deres institutioner kanalisere de ressourcer, de trods alt har, over i samarbejde med bibliotekerne, i stedet for at publicere elektronisk i eget regi eller at søge andre partnere. Hvis jeg har ret i, at der er stadig er væsentlige tekniske problemer, som skal løses, før humanisternes produktion af fagbøger på tilfredsstillende måde kan ske i elektronisk form, så er der brug for et praksisrettet udviklingsarbejde på dette felt. Og hvis jeg har ret $\mathrm{i}$, at humanisternes publikationer tilbyder strategiske muligheder for at forskningsbibliotekerne også i den elektroniske verden kan være vigtige opbevaringssteder for informationsmateriale og vigtige led i processeringen, så er der grund til at bibliotekerne forstærker den satsning på elektronisk publikation, som allerede er i gang. Dermed skulle det være muligt at slå forskningsbibliotekernes og humanisternes problemer sammen, så de kan blive til løsninger for begge parter.

På kort sigt er de "strandede" tidsskrifter et oplagt sted at starte. Her er der udelukkende organisatoriske spørgsmål at løse. Tekniske problemer er der næppe, 
og de økonomiske problemer ser ud til at dreje sig om økonomisk organisation snarere end den samlede mængde ressourcer. På længere sigt må det så være bøgerne, der er i fokus.

\section{Referencer}

Dunne, P \& Hughes, A (1994). Age, Size, Growth and Survival: UK Companies in the 1980s. Journal of Industrial Economics 42:2, 115-140.

History and Computing (1989-2002), vol. 1-14.

Kennan, M A \& Kingsley, D (2009). The state of the nation: A snapshot of Australian institutional repositories. First Monday, 14:2. Lokaliseret 18.1.2010 på WWW: http://firstmonday.org/htbin/cgiwrap/bin/ojs/ index.php/fm/article/viewArticle/2282/2092.

Lind, G (2000). Historiske kildetekster som elektronisk tekst kodet i XML. Skitse til en almen model. Metode \& Data 82, 3-9.
Lynch, C A \& Lippincott, J K (2005). Institutional Repository Deployment in the United States as of Early 2005. D-Lib Magazine, 11:9. Lokaliseret 18.1.2010 på WWW: http://webdoc.sub.gwdg.de/ edoc/aw/d-lib/dlib/september05/lynch/09lynch.html

Thaller, M (1992). Kleio 4. Ein Datenbanksystem. St. Katharinen : Max-Planck Institut für Geschichte in Kommission bei Scripta Mercaturae.

van Westrienen, G \& Lynch, C A (2005). Academic Institutional Repositories. Deployment Status in 13 Nations as of Mid 2005. D-Lib Magazine, 11:9. Lokaliseret 18.1.2010 på WWW: http://www.dlib.org/ $\mathrm{dlib} /$ september05/westrienen/09westrienen.html

Woollard, M \& Denley, P (1993). Source-oriented data processing for historians: a tutorial for Kleiō. St. Katharinen : Max-Planck Institut für Geschichte in Kommission bei Scripta Mercaturae. 